\title{
«Се человек...» (новое о Л.Н. Толстом)
}

(Рецензия на книгу: Жирков Г.В. Се человек... Публицистическое слово Л.Н. Толстого к человеку и человечеству. М.: Флинта, 2019)

Ирина Толоконникова

DOI: 10.30547/mediaalmanah.6.2020.282284

(c) Толоконникова Ирина Владиславовна кандидат филологических наук, старший научный сотрудник кафедры истории русской литературы и журналистики факультета журналистики МГУ имени М.В. Ломоносова, (г. Москва, Россия), ivtol@mail.ru
Исследование профессора Санкт-Петербургского государственного университета Г.В. Жиркова «Се человек... Публицистическое слово Л.Н. Толстого к человеку и человечеству» представляет несомненный научный и практический интерес. В книге собран богатейший фактический материал, который интересен как для специалиста, так и для простого читателя; он не только представляет ценность сам по себе, но и является существенным вкладом в изучение публицистики Толстого. «Глядя на путь Толстого, его судьбу, его творения, хочется утверждать высоким, с большим смыслом древним речением: “Се человек"» (с. 7)1. Этим объясняется название книги.

Монография посвящена публицистической деятельности Льва Толстого, которая с 1880 гг. становится так важна для него самого и получает мировое признание. «Писатель, живший в предчувствии катастроф XX столетия, предлагал российской власти рациональные решения назревших проблем, пытался остановить движение человечества к мировой войне; обратить внимание мировой общественности на духовные и нравственные проблемы, при решении которых была бы предотвращена надвигавшаяся трагедия. Публицистика писателя контролировалась властью особенно жестко, но он, как никто другой в России, сумел добиться свободы слова 
и высказаться по самым злободневным вопросам эпохи» (с. 2).

Книга состоит из шести глав. Первые две главы («На пути к признанию» и «"Второе рождение" Л.Н. Толстого») посвящены становлению Толстого-публициста, которое началось еще во время Крымской войны, когда в 1853 г. писатель вместе с группой артиллеристских офицеров-сослуживцев решил издавать «Военный листок» - доступный и дешевый журнал, предназначенный для просвещенных солдат и «всех сословий военного общества» (т. 59, с. 296) 2 . Свой план он излагал в письмах С.Н. Толстому (29 ноября 1854 г.) и Т.А. Ёргольской (6 января 1855 г.): «Я задумал основать военный журнал. Проект этот я выработал в сотрудничестве многих выдающихся людей» (т. 59, с. 293-294). Жирков пишет: «Л.Н. Толстой задумал новаторское по типу издание, противопоставляя его официальной военной журналистике. Оно должно было иметь демократическую по тем временам направленность, нести объективную информацию, рисовать правдивую картину военной жизни» (с. 65). Однако Толстому не удалось осуществить задуманное. Николай II не разрешил издание журнала. Это заставило Толстого обратиться в редакции «Современника» и «Русского вестника»: «Я признаюсь, боюсь издавать сам, хлопот и с типографией, и, главное, с цензурой» (т. 83, с. 59).

Тем не менее желание издавать собственный журнал не оставляло писателя в течение ряда последующих лет. Оно было связано с его стремлением к просвещению народа. И он создал педагогический журнал «Ясная Поляна» (1862), который состоял из двух отдельных выпусков: «Ясная Поляна. Школа. Журнал педагогический» и «Ясная Поляна. Книжки для детей». Новаторской чертой журнала было стремление его издателя к широкому участию аудитории в его начинаниях, обратная связь с нею. К сожалению, издание имело мало подписчиков (не более 400) и было убыточным, поэтому просуществовало недолго. Но «Ясная Поляна» сыграла важную роль в развитии школьного дела. Журнал «объединял и организовывал вокруг себя учителей, был трибуной дискуссий и обмена опытом. Он обучал их новой педагогике и умению писать для крестьян», - к такому справедливому выводу приходит Жирков (c. 164).

Кроме того, журнал сыграл важную роль в становлении Толстого-публициста. В этот период жизни «он пишет статьи, обращения, отчеты-исследования; организует с помощью прессы обсуждение проблем педагогики; издает журнал, выпускает книги; вырабатывает новаторские типы изданий - педагогического журнала, ставшего центром собирания и сплочения творческих сил, заинтересованных в народном образовании, и книги, доступной по содержанию и форме крестьянской и детской аудитории. Всей этой деятельностью был сделан значительный шаг в развитии и обогащении русского языка и народной литературы. Этим был заложен фундамент и для последующей издательской и журналистской деятельности Л.Н. Толстого» (с. 178). В этой же главе Г.В. Жирков уделяет много внимания таким важным, основополагающим произведениям Толстого, как трактат «Исповедь» и книга «Так что же нам делать?».

Третья глава («"Посредник" - издательство нового типа») посвящена следующему этапу публицистической деятельности Толстого - издательству «Посредник», которое возникло в Санкт-Петербурге в 1884 г. по инициативе Толстого. Основной принцип работы «Посредника» состоял в издании доступной для народа по цене художественной и нравоучительной литературы. Этот проект поддерживал известный меценат К.М. Сибиряков. Толстой издавалтам свои народные рассказы, считая, что именно на них он должен сосредоточить творческие усилия. «Среди современников Толстого, кстати, существовало представление 
о его народных рассказах как о народной публицистике» (с. 344).

В четвертой главе («Л.Н. Толстой и журналистика») рассказывается о творчестве Л.Н. Толстого в 1890 гг. - это расцвет его публицистической деятельности. Исследование и критика действительности, обличение пороков общества, призыв к их искоренению - «Льву Николаевичу этого было недостаточно: он не мог только звонить в колокол. Стремление к действию, поддержка деятельности других составляют отличительную особенность его публицистического творчества. В этом смысле он опережал Время. Публицист-организатор - одна из специализаций журналиста, которая утвердится в советской России, репортер-макрейкер - явление американской журналистики 1910-1920-х годов» (с. 385). В этой главе также говорится о взаимоотношениях писателя с российскими журналами конца XIX в.: «Русской мыслью», «Русским богатством», «Северным вестником» - теми журналами, где он публиковал свои публицистические статьи. Правда, в печати России того времени - прежде всего по цензурным соображениям - смогла выйти в свет лишь незначительная часть произведений Толстого, многие из которых уже тогда были переведены на иностранные языки.

Пятая глава («Лев Толстой и духовная жизнь общества») во многом посвящена духовным поискам писателя, его отношениям с русской православной церковью и церковной журналистикой.

Шестая глава («XX век: нравственная, политическая публицистика и эссеистика Толстого») характеризует последнее десятилетие жизни писателя. Она, наряду с заключительным «Словом Л.Н. Толстого к грядущим поколениям», подводит итоги всему исследованию, которое, несомненно, будет воспринято филологическим сообществом как новый капитальный труд в изучении Толстого-публициста.

\section{Примечания}

1 Здесь и далее книга Жиркова Г.В. «Се человек... Публицистическое слово Л.Н. Толстого к человеку и человечеству» цитируется с указанием страницы в круглых скобках.

2 Здесь и в далее цитаты Л.Н. Толстого приводятся с указанием тома и страницы цитаты по изданию: Толстой Л.Н. Полн. собр. соч.: в 90 т. М.: Худ. лит., 1928- 1958. 